\title{
Destination images: antecedents of city marketing, tourism event, and social media marketing concept
}

\author{
Aisah Asnawi \\ Faculty of Economics and Business, Pattimura University, Indonesia \\ Correspondence author email: cheasnawi@yahoo.com

\begin{tabular}{|l|l|l|l|l|}
\hline DOI: & Received: & Revised: & Accepted: & Published: \\
10.22437/ppd.v9i2.12742 & 30.04 .2021 & 18.06 .2021 & 25.06 .2021 & 30.06 .2021 \\
\hline
\end{tabular}

\begin{abstract}
Building tourism is long-term work. Many elements are involved, and their effectiveness cannot be calculated partially. At present, competition between cities/districts continues to increase, especially in city/district marketing that is touristfriendly, iconic tourism events, and massive social media marketing. The strong destination image will impact on increasing the number of visits. This research aims to analyze the impact of city/district marketing power, tourist events, and social media on the image of tourist destinations in Maluku. The methodology in this research is based on quantitative analysis using Structural Equation Modelling (SEM) to discuss theory and see the relationship between city/district marketing variables, tourism events, social marketing media, and destination image. This study indicates that city/district marketing has a greater increase in strengthening the image of destinations compared to tourism events and social media marketing. This shows an effective strategy from the government in advancing tourism faster and more robust in increasing the image of a destination.
\end{abstract}

Keywords: City/district marketing, Destination image, Social media marketing, Tourism events

JEL Classification: M30, M31, M37

\section{INTRODUCTION}

In Indonesia, tourism has contributed significantly to increasing foreign exchange. In 2011-2012, tourism became the fifth foreign exchange contributor after the oil and gas, coal, palm oil, and processed rubber sectors. In 2013-2015 the tourism sector increased to rank fourth national foreign exchange contributor, and in 2016 this sector became the second largest foreign exchange earner after crude palm oil (Table 1).

A high and competitive tourism image results from an effective and efficient strategy from various components, including organizing tourism events and destination marketing through social media. The image is an important factor and very influential on visits because it can maintain the market share of tourists, promotions, and price and service sensitivity between repeat and first-time tourists (Alegre \& Juaneda, 2006). Attracting tourists to visit again and/or recommend destinations to others is very important for destination development (C. Chen \& Tsai, 2007). Destination imagery also plays an important role in the decision of the first visit when traveling. (Kaplanidou 
\& Vogt, 2010) Therefore, a positive image felt during a visit to a destination can increase repeat visits. (Pike, 2008) and (Daleela, Wahid, \& Khasimah, 2016). Discussion about tourism is multidimensional, multisectoral, multiskill, and has significant multi-economic and social effects. This is because the basic value of tourism is "spending," which has a multiplying effect on various sectors such as hotels, transportation, trade, crafts, and other services. In addition, tourism is closely related to investment and economic structure in other fields. (Tripkovic Markovic, 2010)

Table 1. National foreign exchange receipt from the tourism sector

\begin{tabular}{cccc}
\hline Years & $\begin{array}{c}\text { Number of International } \\
\text { Tourist }\end{array}$ & $\begin{array}{c}\text { Country Income } \\
\text { (million US\$) }\end{array}$ & $\begin{array}{c}\text { Enhancement } \\
(\%)\end{array}$ \\
\hline 2011 & $7,649,731$ & $8,554.39$ & 12.5 \\
2012 & $8,044,462$ & $9,120.89$ & 6.6 \\
2013 & $8,802,129$ & $10,054.15$ & 10.2 \\
2014 & $9,435,411$ & $11,166.13$ & 11.1 \\
2015 & 9.729 .350 & $11,900.00$ & 6.6 \\
2016 & 11.519 .275 & $13,230.76$ & 11.2 \\
2017 & $14,039,799$ & $16,800.00$ & 26.9 \\
2018 & $15,810.305$ & $17,600.00$ & 4.7 \\
\hline
\end{tabular}

Source: Ministry of Tourism and Creative Economy

Many cities and towns spend large budgets on marketing policies to attract new target groups and maintain existing ones; therefore, differentiation is becoming increasingly important, especially for smaller cities. This differentiation is intended to attract visitors. The reason someone chooses to visit one place compared to other places is very subjective, not only because of attributes but also because something is more dominant or something else. Empirical research shows that policies and strategies of the city increasingly cities as the ability to live, visitability, and ability to invest. In the tourism sector, city/regency marketing is essential in strengthening the city's image as a tourist destination and attracting as many visitors as possible.

One strategy in marketing destinations can be done by organizing tourism events to enhance and shape a positive image of the area. This underlies the Ministry of Tourism to create a Calendar Of Event $(\mathrm{CoE})$ that displays national and international scale events from every province in Indonesia. Tourism events are shown in cultural, historical, and sporting events that can attract domestic and foreign tourists. Many empirical studies state that tourism events effectively invite people to visit, reduce negative images, and even turn them into positive images (Yuan \& Chong, 2007). In Maluku, as one of the provinces in Indonesia, organizing tourist events increased in number from 2015 to 2019. In 2015 there were 15 events to 27 events in 2019. In addition, the holding of the event was not only centered in Ambon City but spread in various districts/cities in Maluku.

Empirical studies also prove that tourism and social media cannot be separated at this time. The development of social media marketing has a significant impact on tourism (Zeng \& Gerritsen, 2014). The development of the internet makes the function of social media increase from just networking to interact to become an effective marketing tool. The use of social media aims to accelerate the process of interaction between information producers and recipients (Sicilia, Perez, \& Heffernan, 2008). Almost all tourist destinations and events currently use social media to promote efficiency and effectiveness in reaching specific interest segments. 
An exciting phenomenon now is increasing the number of websites and blogs that discuss tourism, the tourism community, personal reviews about travel, and even the profession as a traveler and blogger that is increasingly attracting the interest of many people. To promote tourism at a low cost, the Ministry of Tourism invited influencers and social media bloggers from various countries to review destinations in Indonesia. This was done because of their ability to promote and influence their followers to visit Indonesia. In addition to social media platforms such as Facebook and Instagram that are often used, the website also plays an essential role in providing tourist information. The tourist destination has an official website as a source of information that can be used as a tourist reference about all things in the destination, such as accommodation, transportation, entertainment, and local culture. The Ministry of Tourism created the Most Popular Digital Tourism Promotion category in the Indonesian Enchantment Award (API). It supports tourism marketing through digital media. It is to assess the seriousness of each province and community using social media in the promotion of destinations and to encourage regions to play a more significant role in promoting tourism and competition between regions. Contested categories increase every year. In 2016 there were ten categories contested, while in 2017, it increased to fifteen categories. The selection of winners is based on online voting for the public for a certain period.

Some researchers who write about destination images use event tourism and social media marketing variables to increase the impression of tourist destinations. In comparison, the city marketing variable has not been studied much related to the destination's image. Research on city marketing is usually using qualitative methods about the policies of a city. This is an opportunity for researchers to see city marketing as a factor supporting destinations to achieve an optimal image.

Based on the explanation above, this research aims to: 1) Obtaining the effect of city/district marketing on the image of a tourist destination; 2) Obtaining the effect of tourism events on the image of a tourist destination; 3) Obtaining the effect of social media marketing on the image of a tourist destination.

\section{LITERATURE REVIEW}

\section{City/district marketing}

The study of marketing of a place is based on two theoretical approaches, namely; (1) marketing of the place and political economy that emphasizes more on the transformation of government and the involvement of the business community in economic development; (2) concentration of various marketing strategies. (Avraham \& Ketter, 2008).

The difference between destination marketing and traditional marketing is, (1) the destination is more challenging to manage because of the complexity of the relationships between the various stakeholders; (2) many parties are interested in developing, producing, delivering, and offering tourism so that there is no owner of the whole process; (3) related stakeholders in presenting destinations may have conflicts of interest and political agendas making it difficult to work together. (Line \& Wang, 2016).

Over time, the idea that marketing is synonymous with marketing, in general, begins to erode. As a result, communities, cities, countries, nations, and regions have 
become more active in adopting strategic business, management, and marketing concepts and tools. (Gertner, 2011).

The perception of a city/district is essential as a basis for someone's decision to visit a destination in the city /district. Urban marketing is now more positioned as a strategy used to attract tourists and potential investors. Since tourism is a supporting sector to increase regional income and is supported by Law No.32 of 2004 concerning regional autonomy, each city/regency is trying its best to implement appropriate marketing strategies to promote the city/regency.

The special article that discusses the relationship between city marketing variables and city image by Kavaratzis (2004) states that the object of city marketing is the image of a city/destination where it is the starting point for developing city brands. In contrast, Braun (2008) states that city marketing will stimulate competition between cities and a destination/city image. Balencourt \& Zafra (2012) even states that the destination image is central to all marketing objectives of a city. All city assets are strived to improve the city's image to benefit residents, visitors, and prospective residents. Boison (2007), in The Strategic Application Of City Marketing to Middle Size Cities, reveals the strategies of several cities in attracting potential residents and visitors. In this research, it is mentioned that some cities have a bad image, and an effective city marketing strategy is needed to re-image positive and good things about a city.

H1: City/district marketing has a positive and significant effect on destination image.

\section{Event tourism}

Many academics have studied the relationship between tourism event variables and destination imagery. Some of them are (Boo \& Busser, 2006), (Werner, Dickson, \& Hyde, 2016), (Yuan Liu \& Chen, 2007), (Kaplanidou \& Vogt, 2010) (Yi-de Liu, 2014) (Dimanche, 2016) ), (Lai, 2016).

Research on the relationship between tourism event variables and destination images conducted by Dimanche (2016) explains tourism events used to position and strengthen destination images among competitors. Lai (2016) states that, in general, the image of an event influences the destination image. Kaplinadou (2010) states that there is a significant influence between the image of a sports event on the destination image

Events are important motivations that play a role in developing and marketing most destinations through local, distinctive, unique, and regional icons. (Middleton \& Clark, 2001). Events that are well planned and documented will play a role and positively impact the competitiveness of destinations (Getz, 2008); (Golob \& Jakulin, 2014). In recent years, special festivals and events have become one of the fastestgrowing types of tourist attractions (Thrane, 2002); (Gursoy, Kim, \& Uysal, 2004). There are several potential reasons for this phenomenon, (1) Festivals and tourism events have a significant effect on the economy; (2) sponsors have the confidence to get intangible social benefits through participation in events; (3) developing a new festival is a strategy to extend the life cycle of a destination (Boo \& Busser, 2006). In addition to positive images, events or festivals can also erase negative effects. A city with a unique image can be identified through city mind identity, city visual identity, and city behavior identity related to events and festivals (Yuan Liu \& Chen, 2007).

The effect of the event on social, environmental, and economic aspects was also raised by Raj \& Musgrave (2009). Thus, it can be concluded that the event has positive effects and negative effects that the event organizer and stakeholders must anticipate. 
While the primary purpose of the tourism event can be described as follows (Getz \& Page, 2016): 1) Attract tourists (including sponsors and media), economic benefits; overcome the weak season, spread the geography of tourism, and enhance urban and economic development; 2) Spread a positive image of the destination, build the city's brand and reposition the city's image; 3) Contribute to marketing destinations as places that are suitable and attractive; 4) Describe a city, resort, park, urban spaces, and all types of places to get repeat visits; 5) Development catalysts, including urban renewal, community capacity building, volunteerism, and improving marketing to produce longterm inheritance.

Based on the typology of the event, it can be concluded that almost all typologies have in common. Eight typology events from Getz (2008); and Golob \& Jaculin (2014) have similarities in overall typology. Middleton \& Clark (2001) even have ten typologies but are different from other researchers because they emphasize event objects. Thus, it can be concluded that the event is about cultural celebrations and politics, arts, education, sports, and other entertainment celebrations.

$\mathrm{H} 2$ : Event tourism has a positive and significant effect on destination image.

\section{Social media marketing}

Research on the effect of social media marketing variables on destination images is discussed by (Kiralova \& Pavlí, 2015), (Jabreel, Moreno, \& Huertas, 2016), (Tham, Croy, Mair, \& Croy, 2013), (Mariani, Di, \& Mura, 2016), (Zhou \& Wang, 2014). In a study conducted by (Kiralova \& Pavlí, 2015), the magnitude of communication in social media on tourism destination strategies can ultimately strengthen the destination's image. Jabreel et al., 2016) looked at the effect of social media on destination images through qualitative and quantitative reference mapping. (Jabreel et al., 2016).

The internet has revolutionized business, including the tourism sector. Reviews generated from visitors, photographs, videos, stories and recommendations, and destination marketing online make it easy to reach potential visitors. (Kiralova \& Pavlí, 2015). Social media marketing revolutionizes the concept of communication of tourist destinations and plays an essential role as a source of tourism information (Xiang \& Gretzel, 2010). It plays a significant role on the demand-supply side. It allows tourist destinations to interact directly with visitors, make offers, get input and be more efficient in evaluating service than traditional communication. (Kaplan \& Haenlein, 2010); (Pavlí, 2015).

Most social media marketing research in tourism is related to the phenomenon from tourists' perspective (Ayeh, Leung, Au, Law 2012) and its relevance to travel information seeking and behavior. Research on this topic shows that prospective tourists trust the credibility of blogs more than the traditional word of mouth (Litvin, Goldsmith, $\&$ Pan, 2008). The relationship between blogging and positive sentiment on website advertising, the impact of social media sites on the search for tourist information (Huang, Chou, \& Lin, 2010), and the increasing role of word of mouth electronically (Xiang \& Gretzel, 2010).

Consumers use social media to post stories, comments and evaluations, pictures, and video clips. Tourists share their evaluations and perceptions about a destination with a tendency to influence destination choices for others who are potential tourists around the world. Before, during, and after holidays, social media share experiences and are a significant information source (Kladou \& Mavragani, 2015)). The phenomenon that occurs today, word of mouth electronically, is highly emphasized because social 
media content is considered more trustworthy than the official website of the tourism department or advertisements on conventional media (Fotis et al., 2012).

H3: Social media marketing has a positive and significant effect on destination image.

\section{Destination image}

Brand strength is an asset in the global market strategy. Many researchers have made different contributions to the understanding of destination imagery over the past 30 years. Destination image has become the dominant of the marketing research area in the field of tourism. Attracting tourists to visit again and/or recommend the destination to others is very important for destination development (Chen \& Tsai, 2007).

As a consequence of increased competition in the tourism sector, destination image has become a key element in differentiating between destinations (Hosany, Ekinci, \& Uysal, 2006). Destination imagery has also been an important issue in research in the tourism industry for a long time. This began when many countries used global marketing to promote and support the image of a destination to compete with other destinations. (Huang \& Lin, 2009). The importance of the destination image is recognized as influencing the individual's subjective perception and consumer behavior towards a destination. (Kaur \& Chauhan, 2016).

Most researchers understand the concept of destination images as behaviors formed by cognitive, affective, and conative elements. Each element is part of the construct of behavior and has been shown to influence consumer behavior.

Based on the above literature review, the following hypothetical models are built:

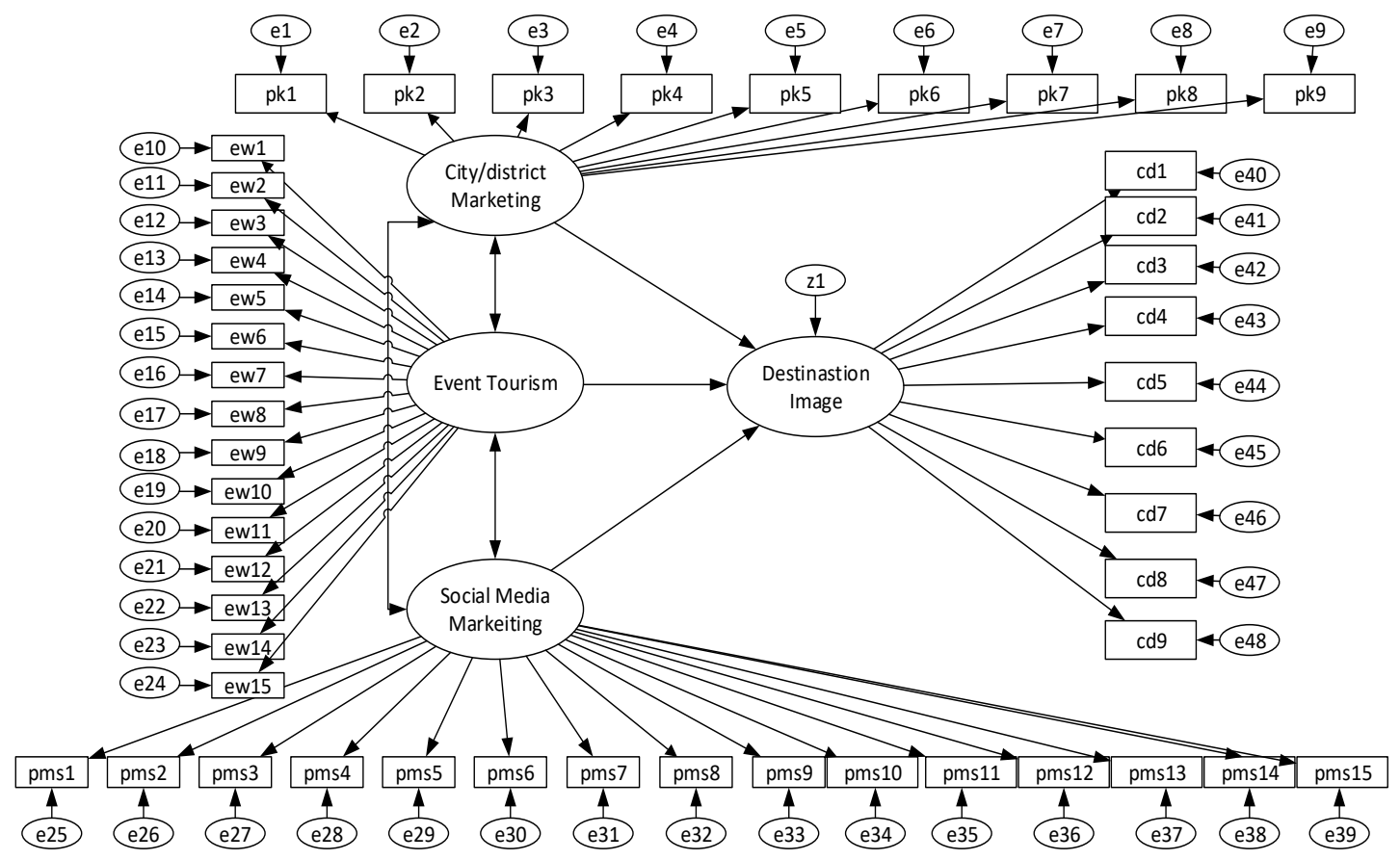

Figure 1. Research hypothesis model

\section{METHODS}

This research uses the verification method with Structural Equation Modeling (SEM) analysis tool. The study's period is cross-sectional one shot, which means that the information or data of this study was obtained at a certain period. The observation unit of the study was 595 domestic and foreign tourists with the aim of leisure and 
attending MICE events (meetings, incentives, conventions, and exhibitions) in Maluku. Data were collected by using the offline questionnaire survey method. The accidental and snowball sampling method was used to collect data from respondents.

\section{RESULTS AND DISCUSSIONS}

\section{Effect of City/district Marketing on Destination Image}

Based on the partial test results, the hypothesis of the city/district marketing variable $(\xi 1)$ has a significant effect on the destination image $(\eta 1)$ with a total effect of $39.9 \%$ with strong criteria. This test illustrates that the marketing of the city/district has a significant effect on the destination image with $t$ count (4.42) greater than the table (1.96). This shows that the hypothesis is accepted. For more details, it can be described in Figure 2.

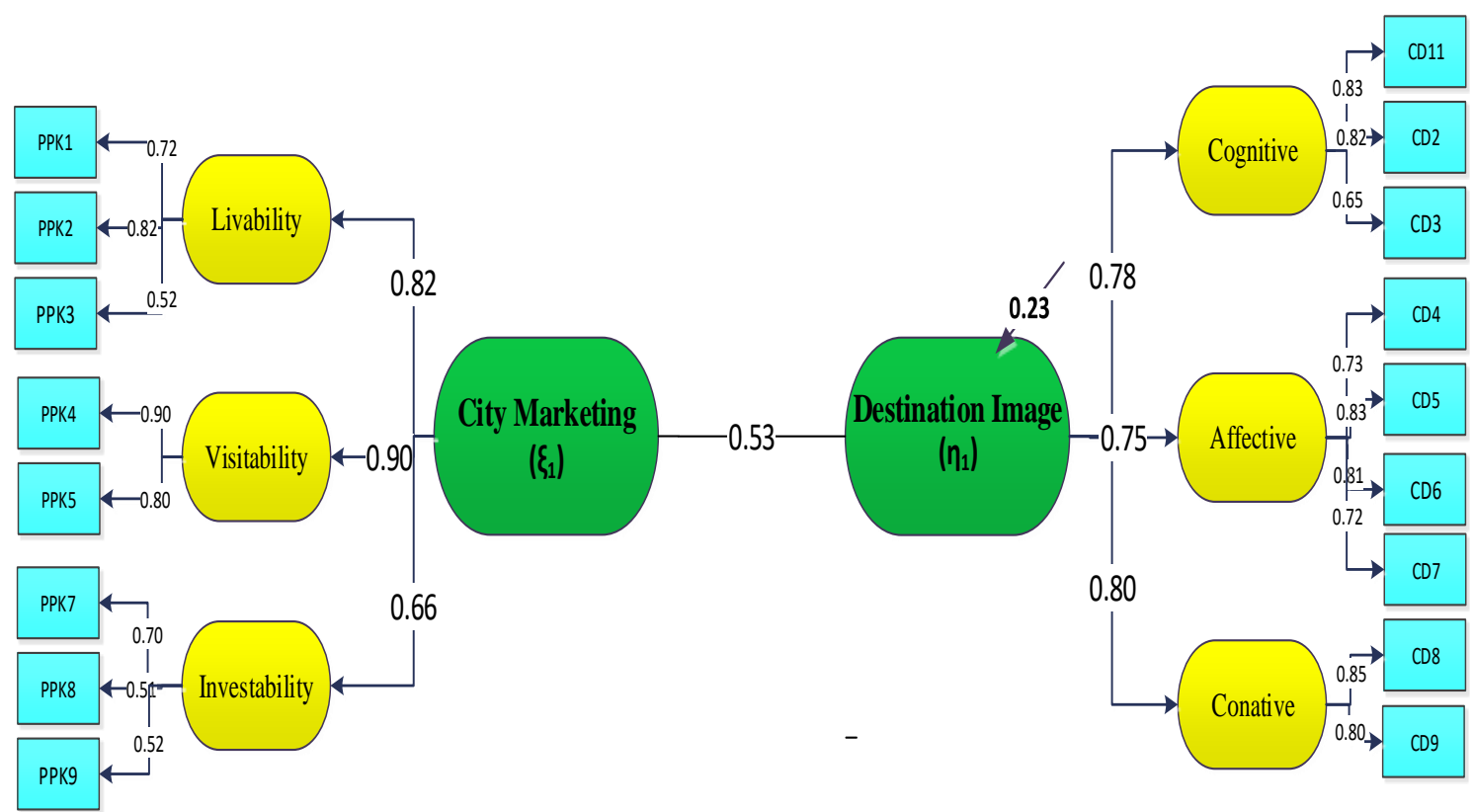

Figure 2. Test results effect of city/district marketing on destination image

In Figure 2, the study results show that city/district marketing consisting of the ability to live, visitability, and instability affects the destination's image. It caused by the policy of the city/district government in the development of tourism is very influential on the image of the city/district. The highest dimension forming destination image is visitability, with a value of 0.90 . At the same time, the livability dimension plays a role in improving the destination image by 0.82 . The development of infrastructure causes this high number to improve facilities and infrastructure to facilitate access to several destinations that impact improving the tourism sector. The investment dimension with a value of 0.66 shows that economic development and investment are also developing so that Maluku is not behind other provinces. Investability in city/regency marketing has a role in increasing investor confidence and business opportunities to increase the destination area's economy. This is in line with Balencourt \& Zafra (2012), who concluded that the marketing strategy of the city/district in terms of improving the regional economy and the tourism sector significantly improves the image of a destination. 


\section{Effect of tourism events on destination image}

Based on the partial test results, the tourism event hypothesis ( $\xi 2$ ) significantly influences the destination image $(\eta 1)$ with a total effect of $23.8 \%$ with moderate criteria. This test illustrates that tourism events significantly affect destination images with $t$ arithmetic (3.90) greater than t table (1.96). This shows that the hypothesis is accepted. For more details, it can be described in Figure 3:

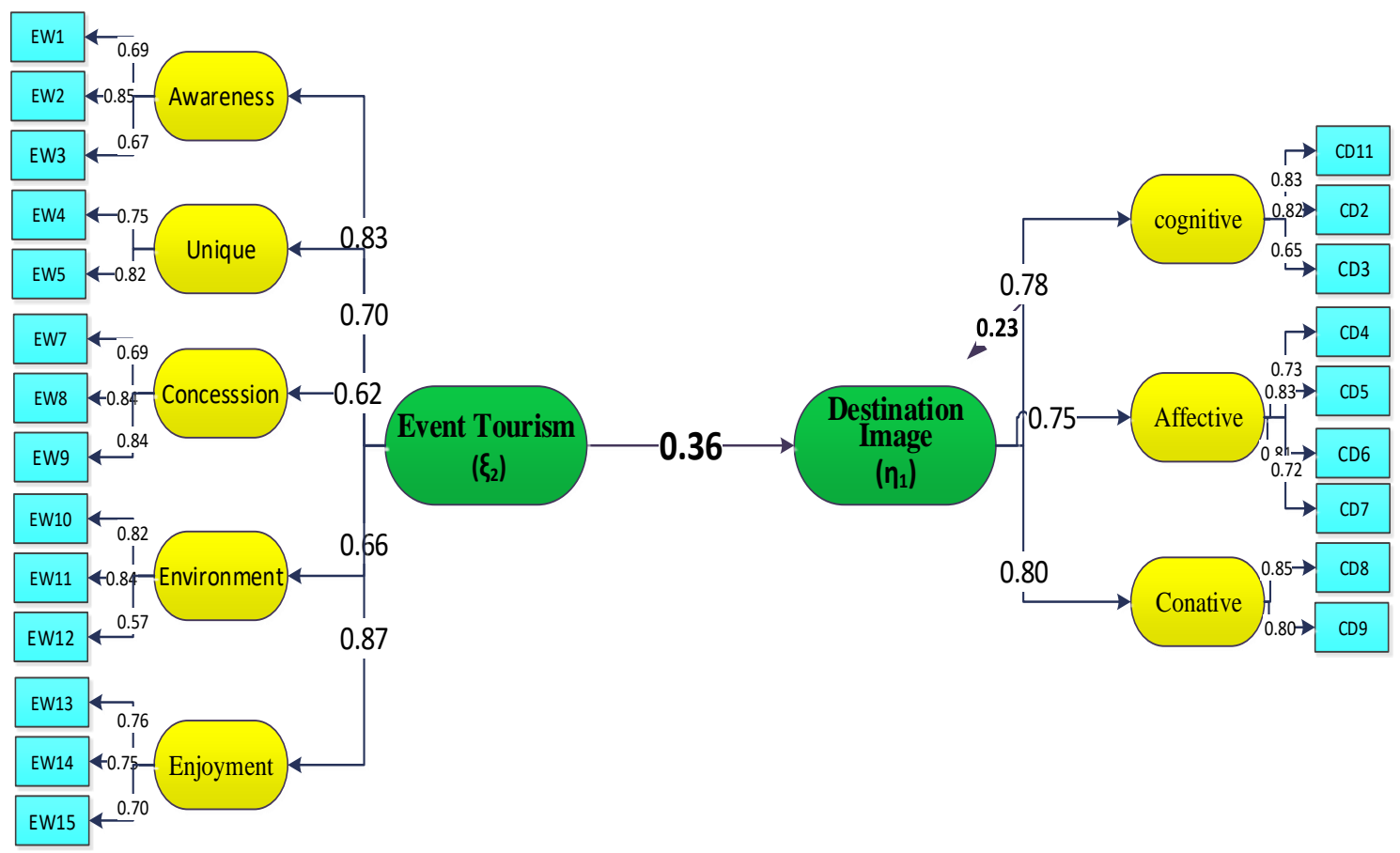

Figure 3. Test results of the effect of event tourism on destination image

In Figure 3, the research results show that tourism events measured through dimensions of awareness, uniqueness, concessions/benefits, environmental readiness, and enjoyment/escape affect the destination image.

The highest value in the tourism event variable in shaping the destination's image is enjoyment, with a value of 0.87 . This is because tourists and visitors feel the fun and enjoy the events carried out. An event is a celebration that can entertain and provide experience; therefore, this aspect is very important for participants or tourists. This is in line with the statement from Getz \& Page (2016) that one of the objectives of participating in the event is that participants try to find personal and interpersonal respect and hope to escape from environmental, personal, and interpersonal aspects that disturb or bore them.

As such, events are an important motivation for tourism and play a role in the development and marketing of most destinations (Middleton \& Clark, 2001). The event also aims to attract tourists, spread a positive image (Getz \& Page, 2016), and contribute to destination marketing because it helps create or maintain an image of a destination. More specifically, events can be used to help promote, position, and build a destination brand. (Dimanche, 2002). Contrary to this study's results, Boo \& Busser's research (2006) show that the event held in Macau did not positively affect the destination's image on the participants. 


\section{Effect of social media marketing on destination image}

Based on the partial test results, the social media marketing hypothesis ( $\xi 3$ ) significantly affects the destination image $(\eta 1)$ with a total effect of $13.4 \%$ with very weak criteria. This test illustrates that social media marketing significantly affects destination images with t count (3.13) greater than the t table (1.96). Although weak, the hypothesis is accepted because it has a significant effect. For more details, it can be described in Figure 4:

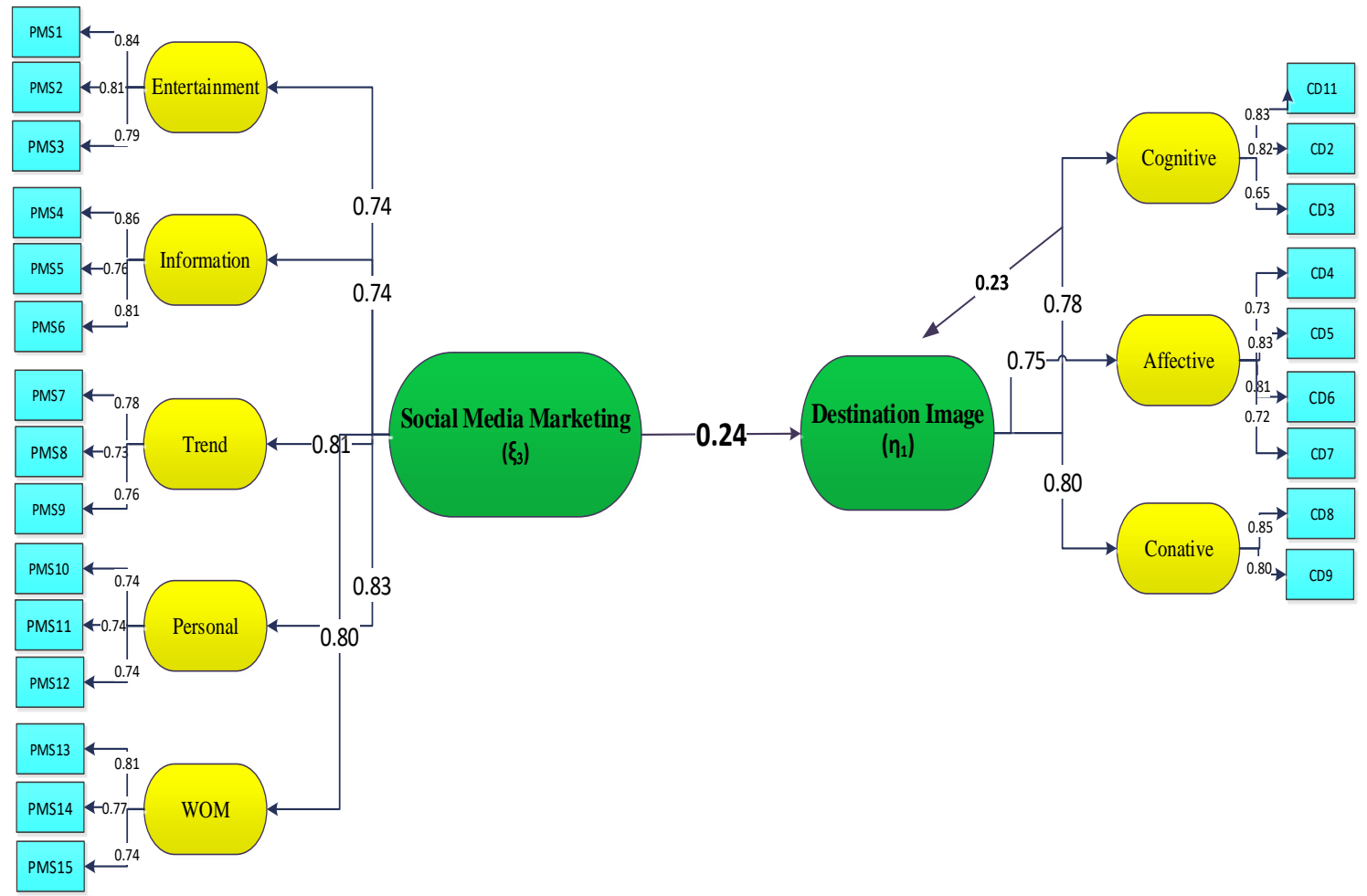

Figure 4. Testing results of the effect of social media marketing on destination image

In figure 4 , the research results show that social media marketing, as measured through the dimensions of entertainment, information, trendy, personalization, and word of mouth, has been proven to affect the image of tourist destinations. Social media marketing affects the image of tourist destinations in Maluku due to several things, including the use of massive social media in social, business, and work-life. In addition, the increase in the community and tourism businesses in doing reviews, photos, videos, and stories about the destinations of Maluku turned out to impact the image of Maluku.

In this calculation, the influence of social media on destination images is $13.5 \%$ and is the variable with the lowest influence compared to tourism events by $28.3 \%$. The maximum use of social media in promoting the Maluku destination is allegedly the low influence of the Maluku destination image. Nowadays, Maluku tourism promotion is more likely to be carried out by tour guide communities, resort owners, and other tourism communities. They also rely on friendship and networking with other parties. Although the number of uses of social media has increased, it has not influenced the image of Maluku tourism.

Social media facilitates tourism promotion because social media marketing helps revolutionize the communication concept of tourist destinations and plays an important role as a source of tourist information (Xiang \& Gretzel, 2010). Reviews generated from visitors, photographs, videos, stories and recommendations, and destination marketing 
online make it easy to reach potential visitors. (Kiralova and Pavli, 2015). Research conducted by Mariani and Mura (2016) even emphasizes the relationship between social media marketing variables and destination image. Research using the mixed method has concluded that social media marketing contributes to building a positive destination image. Kim, Lee, Shin, \& Yang (2017) emphasize the influence of information quality on social media and government-owned websites in improving the image and influencing someone to visit or not to a destination.

This study is in line with research from Werner (2016), (Liu 2015), and Dimanche (2016), which states that tourism events affect the image of a destination. In addition, this study is also in line with Tham (2013), Mariani (2015), and Jabreel (2016), which states that social media marketing influences the image of the destination. If seen from the current phenomena, social media marketing can be a means of promotion with a low budget but has a high impact as an alternative in improving the image of a tourist destination. However, it turns out that the effectiveness of cost-effective tourism events is still considered high in tourist perceptions compared to social media marketing.

\section{Effect of city marketing, tourism effect, and social media marketing on destination image}

The results for the effect of city/district marketing, tourism events, and social media marketing on the image of the destination, the structural equation is hypothesized as follows:

$$
\begin{aligned}
& \eta 1=\gamma 11 \xi 1+\gamma 12 \xi 2+\gamma 13 \xi 3+\zeta 1 \\
& \eta 1=0,53 \xi 1+0,36 \xi 2+0,24 \xi 3+\zeta 1
\end{aligned}
$$

The results of simultaneous hypothesis testing show that overall, city/district marketing variables $(\xi 1)$, tourism events $(\xi 2)$, and social media marketing ( $\xi 3)$ have a simultaneous effect on destination image variables $(\eta 1)$ by $77 \%$ with solid criteria. Therefore, it is concluded that the test results describe changes in city/district marketing, tourism events, and social media marketing that together can improve the image of the destination.

The effect of city/district marketing, tourism events, and social media marketing is caused by the city/district development strategy that has been carried out by the government so far has gone well and made Maluku considered equal to other provinces. In addition, tourism events and social media marketing that have been carried out have improved the image of Maluku destinations.

This research is in line with Balencourt \& Zafra (2012), which states that city/district marketing and the development of the tourism sector will strengthen the destination's image. Meanwhile, Hudson et al. (2015) describe the influence of tourist events and social media as a vehicle for branding a city to improve the destination's image and the perception of the city's people.

\section{Discussions}

Many cities/districts are trying to improve the image of tourist destinations through marketing programs in the tourism sector. Most cities/districts rely on promotion through events tourism and social media marketing. Therefore, this study examines the most dominant variable in improving the image of a destination. The results showed that a city measured through the dimensions of worth living, worth visiting, and worthy of investment has more influence on tourists' perception in assessing the destination's image. 


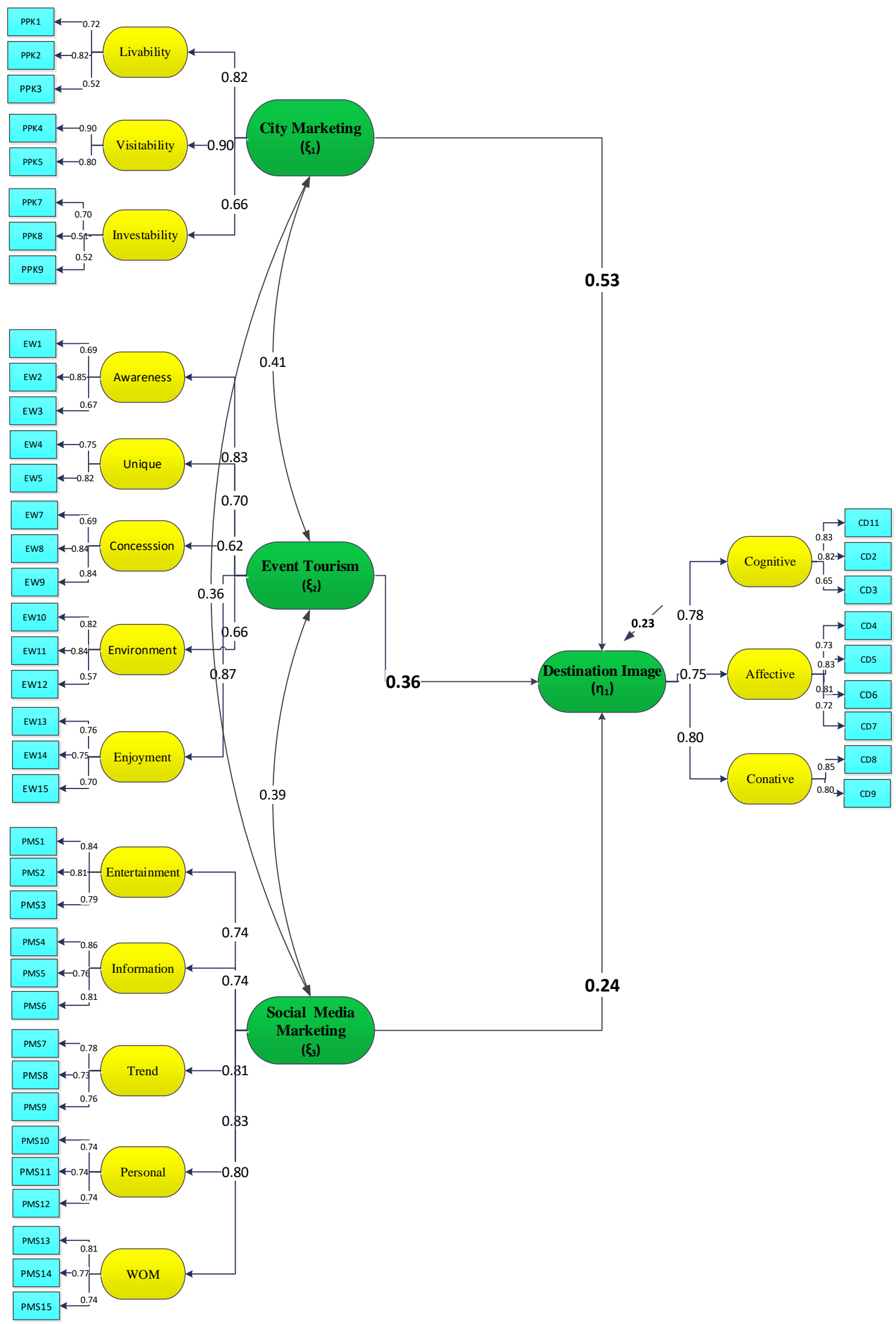

Figure 5. Results of the simultaneous effect of city/district marketing, tourism events, and social media marketing on destination image 
City marketing variables are generally analyzed qualitatively or as respondents to the leaders of a city/district, but this study used tourists as respondents to be different from previous studies. This shows that the policies of city/district leaders in developing the tourism sector must be comprehensive, starting from increasing the welfare of the citizen to ease of investment that has an impact on the image of the city/district that has many tourist destinations.

The relationship between city/district marketing variables, tourism events, and social media marketing simultaneously has a significant relationship. Where if these three variables increase, the image of the destination will also increase. If calculated simultaneously, the effect of the three exogenous variables is higher than the partial calculation.

Increasing the marketing of cities/districts will improve the image of the city. The awareness of the city is increasing and worth visiting, worth living because security, comfort, and infrastructure are important elements in tourism. The coefficient of the city/district marketing channel, if calculated partially, is higher than tourism events and social media marketing. This indicates that city/district marketing is more dominant in increasing the destination's image than tourism events and social media marketing.

\section{CONCLUSIONS, RECOMMENDATIONS, AND LIMITATIONS}

\section{Conclusions}

City/district marketing has a significant influence on the destination's image through livability (worth living), visitability (worth visiting), and investment (worth investment). The influence of city/district marketing is stronger compared to tourism events and social media marketing. This shows that tourists see a city/district as a tourist destination if the commitment of the city/district government is strong in supporting the tourism sector. Tourism events also significantly affect destination imagery through public awareness of event organizing, event uniqueness, benefits, and event readiness.

The holding of events in Maluku increased in quantity and quality. In 2018 there were four events on an international scale and three events included in the national calendar of events. The benefit gained through implementing the calendar of events by the Ministry of Tourism is the broad promotion of events held in Maluku and Maluku increasingly recognized as tourist destinations. The increasing image of Maluku is also caused by a series of international events held by the Ministry of Tourism for two years, from 2017-2018 through Wonderful Sail Indonesia. In this event, 120 yachts from fifteen countries visited three districts in Maluku and other regions in Indonesia. This is a world-scale event that is quite uplifting the image of Maluku as a maritime destination because, for three days, the participants were invited to enjoy Maluku's tourist, artistic and cultural destinations. Based on observations at the location of the activity and interview, participants were very happy to participate in the activity because they had the opportunity to see firsthand the beauty of Maluku, and their perceptions were very positive towards Maluku as an attractive tourist destination.

The personalization dimension in social media marketing has the highest value in shaping the destination's image. This is because social media plays a very important role in providing personal information to tourists based on each tourist's travel preferences. Destination promotion is more effective if done through social media platforms that are directly directed to tourists according to segments and target markets. Tourists also tend 
to look for specific information about the destination and compare it with other similar destinations. Even some visits to destinations tend to be caused by the influence of social media. Therefore, personalization can help strengthen the image of the destination to be more attractive to tourists.

\section{Recommendations}

Qualitative and quantitative studies on city/district marketing, tourism events, and social media marketing in tourism are still needed to increase local revenue or the country's foreign exchange and social and institutional aspects because tourism is multi aspects and multiply effects. Further research can be developed in tourism, such as tourists, travel patterns, shopping behavior, stakeholder perspectives, destination images, and economic returns from investment.

\section{Limitation}

Dimensions and indicators in this research were adopted from previous researchers. Not much has been done about the concept of city marketing in its role in the tourism industry, moreover using tourists to measure the effectiveness of city policies. Many other variables can be explored in shaping the image of a destination. The city marketing variable turns out to be unexpectedly having the most significant influence in shaping tourists' perceptions of destination image compared to tourist event variables and social media marketing which are very commonly used as influencing factors.

\section{REFERENCES}

Alegre, J., \& Juaneda, C. (2006). Destination Loyalty Consumers' Economic Behavior. Annals of Tourism Research, 33(3), 684-706. https://doi.org/10.1016/j.annals.2006.03.014

Avraham, E., \& Ketter, E. (2008). Media Strategies For Marketing Places In Crisis. Elsevier Inc.

Ayeh, J. K., Au, N., \& Law, R. (2013). Predicting the intention to use consumergenerated media for travel planning. Tourism Management, 35,132-143.

Balencourt, A. \& Zafra, A.A. (2012). City Marketing: How To Promote a City. [Master Thesis]. Umea Universitet. P.8

Boisen. M. (2007). The Strategic Application Of City Marketing To Middle Sized Cities. Faculty of Geosciences, Utrecht University

Boo, S., \& Busser, J. A. (2006). Impact Analysis of A Tourism Festival On Tourists Destination Images. Event Management, 9(4), 223-237.

Braun, E. (2008). City Marketing: Towards an Integrated Approach. [Ph.D. thesis], Erasmus University of Rotterdam)

Chen, C.-F., \& Tsai, D. (2007). How destination image and evaluative factors affect behavioral intentions? Tourism Management, 28(4), 1115-1122

Ching-Yuan Huang, Chia-Jung Chou \& Pei-Ching Lin. (2010). Involvement theory in constructing bloggers' intention to purchase travel products. Tourism Management, 31, 513-526.

Daleela, S., Wahid, M., \& Khasimah, N. (2016). First-time and Repeat Visitors to Langkawi Island, Malaysia. Procedia Economics and Finance, 35, 622-631. https://doi.org/10.1016/S2212-5671(16)00076-9 
Dimanche, F. (2016). From attractions to experiential marketing - The contributions of events to New Tourism From attractions to experiential marketing: The contributions of events to New Tourism. In Kronenberg, C., Müller, S., Peters, M., Pikkemaa, B. \& Weiermair, K. (eds). Change Management in Tourism. Berlin: Erich Schmidt Verlag GmbH \& Co.

Fotis, J. (2012). Discussion of the impacts of social media in leisure tourism: The impact of social media on consumer behaviour: Focus on leisure travel. Available online. http://johnfotis.blogspot.com.au/p/projects.html

Gertner, D. (2011). A (tentative) meta-analysis of the place marketing and place branding literature. Journal of Brand Management, 19, 112-131. https://doi.org/10.1057/bm.2011.13

Getz, D. (2008). Event tourism: Definition, evolution, and research. Tourism Management, 29(3), 403-428. https://doi.org/10.1016/j.tourman.2007.07.017

Getz, D., \& Page, S. J. (2016). Progress and prospects for event tourism research. Tourism Management, 52, 593-631. https://doi.org/10.1016/j.tourman.2015.03.007

Golob, A. \& Jakulin, T.J. (2014). Standardization and classification of events. Singidunum Journal of Applied Sciences, 11(1), 67-73.

Gursoy, D., Kim, K., \& Uysal, M. (2004). Perceived impacts of festivals and special events by organizers : an extension and validation. Tourism Management, 25(2), 171-181. https://doi.org/10.1016/S0261-5177(03)00092-X

Hosany, S., Ekinci,Y., \& Uysal,M.(2006). Destination image and destination personality: An application of branding theories to tourism places. Journal of Business Research, 59(5), 638-642

Jabreel, M., Moreno, A., \& Huertas, A. (2016). Semantic comparison of the emotional values communicated by destinations and tourists on social media. Journal of Destination Marketing \& Management, 1-14. https://doi.org/10.1016/j.jdmm.2016.03.004

Kaur, A., \& Chauhan, A. (2016). Destination image : scale validation and measurement invariance analysis. International Journal Leisure and Tourism Marketing, 5(1), 4-25.

Kaplan, A. M., \& Haenlein, M. (2010). Users of the world, unite! The challenges and opportunities of Social Media. Business Horizons, 53(1), 59-68. https://doi.org/10.1016/j.bushor.2009.09.003

Kaplanidou, K., \& Vogt, C. (2010). The Meaning and Measurement of a Sport Event Experience Among Active Sport Tourists. Journal of Sport Management, 24(5), 544-566.

Kavaratzis, M. (2004). From city marketing to city branding: Towards a theoretical framework for developing city brands. Place Branding, 1, 58-73

Kim, S.-E., Lee, K. Y., Shin, S. Il, \& Yang, S.-B. (2017). Effects of tourism information quality in social media on destination image formation: The case of Sina Weibo. Information $\quad \& \quad$ Management, https://doi.org/10.1016/j.im.2017.02.009

Kiralova, A., \& Pavlí, A. (2015). Development of Social Media Strategies in Tourism Destination. Procedia - Social and Behavioral Sciences, 175, 358 - 366

Kladou, S., \& Mavragani, E. (2015). Assessing destination image : An online marketing 
approach and the case of Trip Advisor. Journal of Destination Marketing \& Management, 4(3), 187-193.

Lai. K (2016). Influence of event image on destination image: The case of the 2008 Beijing Olympic Games. Journal of Destination Marketing \& Management, 7, 153-163 . http://dx.doi.org/10.1016/j.jdmm.2016.09.007

Line, N. D., \& Wang, Y. (2016). A multi-stakeholder market oriented approach to destination marketing. Journal of Destination Marketing \& Management, 6(1), 84-93. https://doi.org/10.1016/j.jdmm.2016.03.003

Litvin, S. W., Goldsmith, R. E., \& Pan, B. (2008). Electronic word-of-mouth in hospitality and tourism management. Tourism Management, 29(3), 458-468. https://doi.org/10.1016/j.tourman.2007.05.011

Liu, Y. (2015). Major event and city branding An evaluation of Liverpool as the 2008 European Capital of Culture. Journal of Place Management and Development, 8(2), 147-162. https://doi.org/10.1108/JPMD-02-2015-0007

Mariani, M. M., Buhalis, D., Longhi, C., \& Vitouladiti, O. (2015). Managing change in tourism destinations: Key issues and current trends. Journal of Destination Marketing \& Management, 2(4), 269-272.

Mariani, M. M., Di, M., \& Mura, M. (2016). Facebook as a destination marketing tool : Evidence from Italian regional Destination Management Organizations. Tourism Management, 54, 321-343. https://doi.org/10.1016/j.tourman.2015.12.008

Middleton, Vi., \& Clark, J. R. (2001). Marketing in Travel and Tourism (Third Edit). Butterworth Heinemann.

Pavlí, A. (2015). Development of Social Media Strategies in Tourism Destination. Procedia - Social and Behavioral Sciences, 175, 358 - 366. https://doi.org/10.1016/j.sbspro.2015.01.1211

Pike, S. (2008). Destination Marketing. An Integrated marketing Communication Approach. Routledge

Sicilia, M., Pérez, R., and Heffernan, T. (2008) How do E.U. Cities Utilise their Websites? A Content Analysis and Suggestions for Improvement. Journal of Internet Businesses, 5, 1 - 26

Tham, A., Croy, G., Mair, J., \& Croy, G. (2013). Social Media in Destination Choice : Distinctive Electronic Word-of-Mouth Dimensions Journal of Travel \& Tourism Marketing, 30(1-2), 144-155. https://doi.org/10.1080/10548408.2013.751272

Tripkovic Markovic, A. (2010). Tourism Planning : Contribution of Tourism To SocioEconomic Development of Montenegro. Tourism and Hospitality Management, 1289-1304.

Werner. K, Dickson G, Hyde K. (2016). Mega-events and increased collaborative capacity of tourism destinations: The case of the 2011 Rugby World Cup. Journal of Destination Marketing \& Management, 5. 227-238 http://dx.doi.org/10.1016/j.jdmm.2015.12.009

Xiang, Z., \& Gretzel, U. (2010). Role of social media in online travel information search. Tourism Management, 31(2), 179-188. https://doi.org/10.1016/j.tourman.2009.02.016

Yuan, L. I. U., \& Chong, C. (2007). The effects of festivals and special events on city image design. Frontiers of Architecture and Civil Engineering in China, 1, 255259. https://doi.org/10.1007/s11709-007-0032-0 
Zeng, B., \& Gerritsen, R. (2014). What do we know about social media in tourism? A review. Tourism Management Perspectives, 10, 27-36. https://doi.org/10.1016/j.tmp.2014.01.001

Zhou L, \& Wang T. 2014. Social Media: A New Vehicle for City Marketing in China. Cities 37(1): 27-32. 